\title{
WAR GAMES: STAGING THE HISTORIES IN AN AMERICAN PRESIDENTIAL YEAR
}

\author{
KATH BRADLEY \\ Nottingham Trent University, United Kingdom
}

\begin{abstract}
This paper examines the ways in which the seldom performed collaborative play, Edward III, was re-contextualised by Barbara Gaines, Artistic Director of the Shakespeare Theater of Chicago, in order to create a specifically presentist piece of theatre making a forceful political statement during the 2016 US presidential election. Edward III formed the opening section of a trilogy entitled Tug of War: Foreign Fire, which continued with Henry V, and Henry VI Part I. The second trilogy, Tug of War: Civil Strife, comprised the remaining two parts of Henry VI and Richard III. The paper will address the rationale behind the selection of these specific plays, and why it was felt unnecessary to fill the historical lacuna created by the exclusion of Richard II and Henry IV Parts I and II. In addition, it will also examine the limitations inherent in the available archival material when researching an ephemeral theatrical event, particularly one which has been edited and directed in order to address issues of immediate political concern. Selected extracts from my own review of the first of these two trilogies will seek to offer a more detailed response than is possible for journalistic reviewers and to provide sufficient background to prove of benefit for future researchers. ${ }^{1}$
\end{abstract}

Keywords: Shakespeare, Histories, Edward III, authorship, presentism, performance, reviewing, archives.

In order to address the ways in which Chicago Shakespeare's two Tug of War trilogies were adapted to comment specifically on aspects of US politics during the increasingly acrimonious presidential election campaigns of 2016, this paper draws upon those records most closely concerned with the production of an

\footnotetext{
${ }^{1}$ Elements of this paper have been taken from the author's review of Tug of War: Foreign Fire, which appeared in Cahiers Élisabéthains: A Journal of English Renaissance Studies, vol. 91, 1, 103-106. (1 November 2016). http://journals.sagepub.com/doi/full/10.1177/0184767816669040b
} 
essentially ephemeral theatrical event. These include those resources produced by the company during a production, which will then form part of their own archives, such as prompt books, production images, and marketing material, as well as the responses recorded by journalistic reviewers. As Paul Prescott notes,

Of all the textual inscriptions of performance, journalistic reviews are both the most widely circulated and the most influentially constitutive of memory and value. Reviews have been the primary vehicle in which performance is described and evaluated, and through which vicarious experience, opinion and reputation are propagated. (Prescott 4).

In addition, consideration should be given to the fact that such journalistic reviews generally reflect most closely an audience's immediate response to a theatrical production. Any production staged from a specifically political and presentist perspective is, of course, dependent on an audience's shared knowledge and experience in order to facilitate an appropriate understanding of that production. Such issues must be considered when examining and assessing the use of any primary research material in connection with an ephemeral theatrical performance. The opportunity to attend in person the first of these trilogies and to hold discussions with some of the theatrical professionals concerned contributed valuable insights into these productions and provided key primary resource material. Personal interviews and email exchanges with Barbara Gaines, the director of both trilogies, although naturally reflective of her personal intentions, assisted greatly in obtaining insight into the rationale for producing these plays during a presidential election year. However, the limitations inherent in the subjectivity of producing, selecting and maintaining any archival records of ephemeral events must always be borne in mind as these can be influenced by financial considerations as well as the time available to those involved in maintaining the archives themselves. The detail recorded within a production's prompt book, for instance, is usually the responsibility of the stage manager, often the busiest member of the production team throughout the rehearsal process. How these productions are a practical demonstration of presentist theory at work will be highlighted, alongside the difficulties encountered when recording for archival purposes the specifically ephemeral nature of a theatrical production influenced by contemporary events.

The first of these trilogies, Foreign Fire, comprised a six-hour production combining Edward III, Henry V and Henry VI part 1, and opened the company's commemoration of the $400^{\text {th }}$ anniversary of Shakespeare's death, running from 12 May to 12 June 2016. The second trilogy, Civil Strife, comprised the remaining parts of Henry VI, and Richard III and opened three months later. Terence Hawkes's definition of presentism as an approach to "reading the literature of the past in terms of what most 'ringingly chimes' with the modern world" (Hawkes 22) is exemplified by the textual and theatrical 
choices made when staging these trilogies. Just as Ewen Fernie argues that "Hamlet's singular dramatisation of spiritualised violence compels us to confront the defining issue of our present: terrorism" (Fernie 169), the two Tug of War trilogies encouraged audience members to confront the personal consequences of the ongoing war on terror. However, the term "presentism" itself raises issues, particularly when used in relation to Shakespeare's history plays, and any record of an ephemeral "presentist" performance almost immediately becomes a form of cultural historicism, just as the events upon which the production seeks to comment themselves become history. The analysis of any production seeking to have an impact when speaking directly to the present is, therefore, dependent upon an audience's clear understanding of the issues influencing it. This, in turn, creates challenges for those seeking to record the production for a posterity in which those issues are no longer immediate and comprehensible.

All six of these plays were edited and directed by Gaines, with less concern for issues surrounding authorship than with the overt intention of making a personal and contemporary political statement. Her programme notes for the first trilogy state that "We will see that parabola of war and peace, of why wars begin and begin again. And again" (Gaines 5) and shared a page in that programme with George Santayana's famous quotation "Those who do not remember the past are condemned to repeat it". (Santayana qtd in Gaines 5). Although every theatre company makes individual choices about what production archives must comprise, this programme will form a key component of archives for these productions, alongside such things as the prompt books and production images. The selection of music listed in the programme will also serve to give a sense of Gaines's imperative for the textual choices recorded in the prompt book, but none of this archival material records the specific political situations which informed the production choices made. Nor can journalistic reviews, generally limited both by the requirement to meet a publication deadline and the amount of space allocated to such reviews, reflect in any detail the political situation surrounding the production. The required time for reflection on a performance and the rationale behind the directorial decisions made are usually available only to an academic reviewer producing an article such as this. This paper, therefore, addresses both the performances themselves and the political environment in which they were produced, which shifted throughout the run.

That Gaines was adapting these plays in order to make a specific and presentist political statement was confirmed when, in a personal interview, she was asked whether it was a deliberate decision to stage these plays at a time of social and international unrest. Her response was unambiguous: 
Of course! We've been suffering. We have caused a lot of suffering in the world and we are suffering from being in the longest war in American history. And yet the Congress, all those courageous congressmen, have not yet declared war, so there's something so phony, so fishy, so wrong about what we are doing. (Gaines personal interview).

Gaines's personal imperative to make a strong statement concerning such overseas interventions by her government led her to include Edward III within the first trilogy, at the expense of the more usual Henry IVs and leaving an historical lacuna more usually filled by Richard II. The decision to incorporate Edward III may, therefore, initially appear to have been an odd choice but, within the context of Gaines's intention to drive home the cyclical and wasteful nature of war, the placing of this play immediately before Henry $V$ powerfully reinforced her message. It should also be borne in mind that Edward III is not the only collaborative play included in Gaines's productions, merely that it is the only non-canonical play. Neither this fact, nor Christopher Marlowe's contribution to the Henry VI trilogy, were acknowledged in the advertising material or the production programme. Indeed the entire cycle of six plays was promoted as an opportunity to "Follow the rise and fall of Shakespeare's kings, and the uncommon courage of common men" (Chicago Shakespeare Theater advertising material). The omission of the two sole-authored Shakespeare plays, Henry IV Parts 1 and 2, ensured that Edward III became a companion piece to the more regularly performed canonical play, Henry $V$, whose narrative it so closely mirrors. That it was also intended to make another powerful statement, concerning the impact of foreign wars on the ordinary soldier, was evident from the moment the trilogy began and was unanimously referenced in critical reviews. Editing the text to achieve a running time which was audience friendly whilst emphasising her particular directorial imperative involved cutting heavily all the plays including the text of the first two acts of Edward III, thus losing much of the contribution to the text generally attributed to Shakespeare, another indication that authorial attribution was considered less important in this context. Those scenes present Edward's failure to seduce the Countess of Salisbury, both through personal appeals to her oath of fealty and the forced intercession of her father, the Earl of Warwick and were not, therefore, essential to the overall theme of the production. Gaines's direction did, however, overcome a major structural difference between the sole-authored Henry $V$ with its incorporation of a Chorus, and its two collaborative companions in this first trilogy. A clear structural coherence between the plays was, however, achieved by the distribution of lines from that Chorus throughout the trilogy, with actors taking turns to step forward, wearing a white scarf, to deliver them.

The sparse set comprised an angled thrust stage, which appeared to be supported on rocks representing the shores of England and France, whilst the proscenium area comprised high sections of scaffolding with a number of 
ladders connecting different levels. These were used to great effect throughout the productions to illustrate not only the physical distance between the differing status groups, but also the social dynamics that allowed powerful noblemen to look down upon the struggles of the powerless common man fighting on their behalf. The ambitions of kings and the lust for power of their noble followers were presented as a children's game, as the production began with the lowering of a spray-painted tyre swing to the centre of the stage. This "golden round" (Macbeth 1.5.27) served as a throne over which kings wearing paper crowns squabbled, like children pushing each other off playground equipment. The solipsism of such leaders was emphasised as each king appeared wearing robes emblazoned with his own image.

As the company of 19 actors gathered on stage, kings and nobles randomly distributed to them torn pieces of cloth, red representing the English army and blue for the French. Throughout the trilogy many of these recipients re-appeared wearing the colours of the opposite side, a decision Gaines described as having been influenced by the limited number of cast members available (Gaines personal interview). However, it also had the effect of highlighting the fate of conscripted soldiers, forced to participate in wars fought for reasons beyond their comprehension. As soldiers fell dying, they immediately arose, smearing ashes across their forehead, only to return in order to die yet again on another foreign field. The exclusion of Henry IV Parts 1 and 2 from this sequence also served to emphasise this point. By removing the comic potential of Nym, Bardolph and Pistol featured in those plays, Gaines was able to present them more clearly as victims of conflicts they neither instigated nor understood. Live music was also used to great effect throughout both trilogies, and became another point of symmetry between the two. Provided by a four-piece rock band situated upstage left, it emphasised the central themes of the productions and reflected ongoing political debates surrounding Western engagement in wars where young men and women must fight and die. Henry V himself played lead guitar at times, as actors stepped in and out of the action to perform pointedly political musical choices spanning the period from the American Civil War to the Second Iraq War. Tim Buckley's 1960s protest No Man can Find the War and Frank Loesser's 1942 anthemic Praise the Lord and Pass the Ammunition amongst others underscored the action. The first trilogy concluded as the entire company came together for a rendition of Leonard Cohen's hard-hitting There is a War. As actors stepped forward in sequence to receive torn rags no longer merely of red or blue but covering a wide spectrum of colours as the threat of war engulfed more and more nations, they issued a direct invitation to the audience using Cohen's words "Why don't you come on back to the war, let's all get even."

It is worth noting at this point that all the archival material traced has been mediated through the political sensibilities of theatrical practitioners and 
journalists who, as American citizens, would most immediately be affected by the presidential election result. The sole exception to this was Michael Billington, theatre critic of the UK's Guardian newspaper. The only non-US journalistic response to either Tug of War trilogy is his review of Foreign Fire, in which he signals his own awareness of the political imperatives driving the production, describing the choice of music as reinforcing "its protest against unchecked power and imperialist expansion" (Billington review). His review also includes excerpts from a lengthy interview he had with Gaines whilst in Chicago in which she reiterated the impetus that drove her:

I am angry with my country because of our record of invasion of foreign countries, because people like Dick Cheney and Paul Wolfowitz are not held accountable for their role in this, and because violence has proliferated like a horrific virus. I admit I've always been haunted by the horror of war, which is why I've directed Troilus and Cressida three times, and why I've spent four years planning this Shakespeare history cycle. (Gaines qtd in Billington review).

Such references to key members of George W. Bush's government some years before Gaines even began work on this cycle four years into President Obama's administration set Gaines's primary objective in an historical context. However, they also clearly demonstrate the problems inherent in producing and reporting on theatrical productions which speak to specific events. Although the names of Bush, Cheney and Wolfowitz may resonate for longer in the US psyche than elsewhere, such references indicate that the internet will inevitably become an increasingly important research resource in the future, both to trace relevant online material and in order to establish accurate context. It is, however, clear from Billington's review that what he describes as Gaines's "Brechtian approach" produced "Shakespeare staged with a purpose, and further proof that his history plays speak to us more urgently than ever" (Billington review).

It is unfortunate that Billington did not have the opportunity to view and report on the second trilogy, Civil Strife, which opened on 14 September and closed on 9 October of this year, at a time when even more specific issues had been foregrounded by the ongoing and intensely confrontational presidential campaigns. There were clear parallels drawn between these two trilogies but also more overt references to the election as polling date drew closer. Civil Strife opened with the interpolation of an atextual character of Gaines's own devising. Peters, an unwilling participant in the familial squabbles depicted within this second trilogy, was introduced as the performance began, and his story became a throughline within the Shakespearean narrative. Whilst his wife implored him not to leave for battle, the four kings portrayed in the trilogy appeared in shadow upstage, reprising Cohen's There is a War (which had closed Foreign Fire) urging Peters now to "Come on back to the war, don't be a tourist." Both the 
interpolated character and the music, therefore, combined to link the two trilogies thematically.

Described by one critic as "fully complementary to Gaines' lifelong mission of popularizing, contemporizing, clarifying and Americanizing" the works of Shakespeare, this second trilogy, however, drew even more close parallels between contemporary American politics and the history plays contained within it (Fischer review). This review also highlighted the fact that "playing the demagogic rabble rouser Jack Cade - whose populist, antiintellectual agenda includes punishing people who read and killing all the lawyers - Kevin Gudhal takes to the stage as a dead ringer for Donald Trump" (Fischer review). This overtly political statement, alongside "the use of video, and a simulated newscast" by Trump during Richard III's manipulation of the London crowds, were, Fischer felt, "overly pointed" but were also clearly a presentist shift from a generalised critique of ongoing US foreign policy to a specific commentary on the developing election campaign. Cade here was used to underscore the adoption of an increasingly anti-intellectual stance which led The New York Times to describe the Republicans as "the Stupid Party" (Boot editorial). This, opinion writer Max Boot concluded, had led to a presidential candidate who "truly is the know-nothing his Republican predecessors only pretended to be" (Boot editorial).

These specific references to Trump's divisive presidential campaign ensured that the way in which Gaines presented the battle scenes in both trilogies became more overtly political in the period between the closing of the first and the staging of the second. That none of these battles had been fought with weaponry spoke to the pacifist argument of the production of these conflictdriven plays, but also brought to the fore the ongoing and increasingly virulent debates occurring around the Second Amendment "right to bear arms" during the year. Gaines, although referring to the Constitution as "a blessed document" (Gaines personal interview), vehemently opposes the current interpretation of that Amendment and, as a pacifist statement, rejected armaments in favour of loud music, explosions and pyro-technics in order to create the necessary sense of chaos and fear in the battle scenes. Beyond the end of the run of the first trilogy, such a deliberate staging choice developed even greater retrospective resonance, particularly given Donald Trump's comment that "the Second Amendment people" may hold the solution to their fears that Hillary Clinton "will take your guns away" (Trump speech). Going even further in a later televised broadcast, it was reported that he called for his opponent's bodyguards to "disarm immediately" - adding, "Let's see what happens to her" (Luscombe).

Although the critics were unanimously complimentary about the productions as a whole, they were divided as to the increasingly specific political references in the second trilogy. The Chicago Tribune's Chris Jones felt that "Gaines' overarching aim - of exploring the impact of these wars on the 
ordinary soldiers - was manifest far more powerfully in Foreign Fire than Civil Strife, mostly because the plays in the first part have much better battle scenes" (Jones review). His criticism of the second trilogy centred on what he felt was a shift in emphasis, when the director's "concerns about the current election took over from the longer view" concluding that, in her staging of the Battle of Bosworth Field, "Gaines so badly wants to tell a cautionary tale about the rise of embittered tyrants with charm that she no longer pays as much attention to the grunts dying in the meadow in someone else's name" (Jones review). In contrast, Theatermania's Adelaide Lee opened her review with the statement that "There's nothing like a sequel that's better than the original" (Lee review). She found Civil Strife to be better paced than Foreign Fire, and described the Jack Cade scene as a "a brazenly partisan interlude" portraying the "populist rebel (...) in unmistakable Donald Trump regalia, complete with orange skin and puckered lips"(Lee review). Despite both these critics reading these plays from an increasingly specific contemporary and presentist perspective, it is noteworthy that Gaines had seen parallels between Trump and Cade much earlier. Email correspondence with the Public Relations Manager at the Chicago Shakespeare Theater confirmed that "Barbara made the comparison with Trump long before this election season (...) she was discussing it four years ago! What started as a personality comparison turned into much more when his political rumblings started to align even more directly with Cade's in the play" (Kennedy email).

Such differing critical, and necessarily subjective, responses highlight the difficulties encountered by theatre historians who must rely on such imperfect archival material when attempting to reconstruct an ephemeral theatrical event. Having had the opportunity to attend and review only the first trilogy, I have personally encountered the sorts of issues that arise when the subjectivity of other reviewers cannot be tempered by one's own. Although, as Prescott indicates, such journalistic reviews are "the primary vehicle in which performance is described and evaluated" he acknowledges that they remain records of "vicarious experience" (Prescott 4). As such, it is helpful to draw upon personal experience when assessing their usefulness as research material. This was particularly the case when examining such material as a non-American reviewer analysing a production with a specifically American political agenda. Clearly, too, the greater the temporal and geographical distance between performance and research, the more problematic assessing all such archival evidence becomes. This is particularly true when a decidedly presentist, contemporary, and overtly specific political approach has been adopted. What at the specific moment in time reflected very immediate concerns about the US political situation prior to polling day, must now be read differently as the outcome of the election is known and the arts themselves have been drawn into conflict with the incumbent president. 
President-elect Trump's reaction to the audience of another, and highly successful, theatrical performance is indicative of this. The multi-cultural diversity of Hamilton, a powerful examination of the rise from poverty of one of the Founding Fathers of American democracy, placed it in direct contrast to Trump's protectionist approach to achieving his election promise to "Make America Great Again" (Trump campaign slogan). Thus, when his then vicepresident elect, Mike Pence, was booed by the audience and addressed from the stage by Brandon Dixon, an African American cast member playing an earlier Vice President, Aaron Burr, with the words

Mike Pence, we welcome you here. We are the diverse Americans who are alarmed and anxious that your new administration will not protect us, our planet, our children, our parents, or defend us and uphold our inalienable rights. (...) We hope that this show has inspired you to uphold our American values and work on behalf of all of us. We thank you for sharing this wonderful American story, told by a diverse group of men and women of different colors, creeds and orientations. (Dixon qtd in Walters)

Trump tweeted his displeasure, arguing that the "theater should be a safe place" and demanding an apology. (Trump qtd in Walters). I had previously asked Barbara Gaines asking what opportunity there might be for a future revival of the Tug of War trilogies. At that point, she expressed the hope that touring might be an option, adding "all we need is $\$ \$ \$ \$$ " (Gaines email). In light of then president-elect Trump's reaction to an actor's direct challenge to Mike Pence, and a post-election report on his administration's intention to cut funding to the arts, it is highly unlikely the required finance will become available.

Such swiftly changing political developments create further problems for theatrical productions with a specifically contemporary political agenda. During the run of the Tug of War trilogies, the focus switched from a general statement concerning the impact of foreign wars on the common man to a more specific commentary of the ongoing presidential election. This in turn achieved a greater retrospective resonance for those experiencing the consequences of its outcome. Reviewing such a production for posterity, therefore, becomes increasingly challenging. What is clear, contemporary and immediate in the period during and immediately after the staging of political theatre of this kind becomes blurred with the passage of time. Establishing context, therefore, becomes a key element of any material preserved for archival purposes, particularly when analysing the rationale behind the re-imaging of what comprises a Shakespeare Histories cycle and, hopefully, this paper goes some way to achieving that objective. 


\section{KATH BRADLEY}

\section{Works Cited}

Billington, Michael. "Bard on the Wire: How Chicago scored a hit with Shakespeare and Leonard Cohen." Rev.of Tug of War: Foreign Fire, dir. by Barbara Gaines. The Guardian. 7 June 2016.

Boot, Max. "How the 'Stupid Party' created Donald Trump." New York Times Editorial. 31 July 2016. Web. 17 Oct. 2016.

Chicago Shakespeare Theater. Tug of War: Foreign Fire Advertising Material. 2016. Print.

Fernie, Ewen. "Shakespeare and the Prospect of Presentism." Shakespeare Survey 58 (2005): 169-183. Print.

Fischer, Mike. "Takeaways: Tug of War: Civil Strife." Rev. of Tug of War: Civil Strife dir. by Barbara Gaines. The Journal Sentinel. 26 September. 2016. Web. 2 Oct. 2016.

Gaines, Barbara. Personal email. 17 No. 2016.

Gaines, Barbara. Personal Interview. 8 June 2016.

Gaines, Barbara. "Welcome." Tug of War: Foreign Fire Theatre Programme. 2016. Print.

Hawkes, Terence. Shakespeare and the Present. London: Routledge, 2002. Print.

Jones, Chris. 'Civil Strife concludes Barbara Gaines' epic comment on conflict." Rev. of Tug of War: Civil Strife dir. by Barbara Gaines. Chicago Tribune. 27 Sept. 2016. Web. 30 Sept. 2016

Kennedy, Hannah. Personal email. 19 October 2016.

Lee, Adelaide. "Tug of War: Civil Strife - Chicago Shakespeare Theater's Histories marathon concludes with gusto." Rev. of Tug of War: Civil Strife dir. by Barbara Gaines. Theatermania. 3 Oct. 2016. Web. 4 Oct. 2016.

Luscombe, Richard. "Donald Trump: Clinton's bodyguards should disarm and see what happens." The Guardian. 16 Sept. 2016. Web. 19 Sept. 2016.

Prescott, Paul. Reviewing Shakespeare: Journalism and Performances from the Eighteenth Century to the Present. Cambridge: CUP, 2013. Print.

Trump, Donald. Presidential Election Campaign Slogan. 2016.

Trump, Donald. Rally Speech to National Rifle Association, Wilmington, North Carolina. USNews.com. 9 Aug. 2016. Web. 3 Sept. 2016.

Walters, Joanna. "Trump demands apology from Hamilton cast after Mike Pence booed.” The Guardian. 19 Nov.2016. Web. 21 Nov. 2016. 